\title{
Analyzing of Customer Satisfaction and Customer Loyalty Based on Brand Image and Perceived Service Quality
}

\author{
Genoveva \\ President University, Cikarang, Indonesia
}

\begin{abstract}
Motorcycles market in Indonesia has increased an average of $6.76 \%$ per year. However, growth in the number of motorcycles is not matched by the growth of the number of workshops. Motorcycle repair shop in Indonesia consists of two types: public workshops and workshop by sole agent/dealer. Workshops by sole agent are expected to provide standard services as they relate to the brand image and service quality. Based on the results of a pre-survey of consumer workshop Yamaha in Bekasi, there are indications that consumers are not satisfied with the Yamaha workshop in Bekasi, this can be seen from the complaint that are not well served, waiting time is relatively long, the unavailability of certain spare parts and liabilities wearing the official Yamaha oil. Consumer dissatisfaction resulted in consumer disloyal, which moved to another workshop, the consumer is interested in the promotion conducted another workshop and tends not to give recommendation to others. Based on these problems, the objective of this research was to determine customer satisfaction and loyalty based on brand image and perceived service quality. Research data collection by using a questionnaire distributed to a sample of 355 respondents from five Yamaha workshops in Bekasi. Data were analyzed by using SPSS 2.0 to test the validity and reliability of the questionnaire. After a valid and reliable questionnaire, questionnaires were returned distributed to respondents, and questionnaire data were analyzed using LISREL 8.7. Based on the analysis of data, it can be concluded that from the seven hypotheses, five of them are significant hypotheses.
\end{abstract}

Keywords: brand image, perceived service quality, customer satisfaction, customer loyalty

The number of middle class in Indonesia is increasing and has the impact to the demand of motor vehicles. The data of Directorate General Transportation inform an increasing number of motorcycle, reaching $6.76 \%$ per year (Industry Assosiation of Motorcycle Indonesia, 2015).

Unfortunately, the developments in the Indonesian automotive industry, are not by the growth in the number of workshops. The Director General of Ministry for Small and Medium Industry, said that these conditions occur, because the existing workshop could only serve about $60 \%$ of after-sales service vehicles, so it is still wide open for business in motorcycle workshop (Abdullah, 2013).

Based on the results of pre-research, according to Yeranto as one head of a workshop in Bekasi, some problems related to lack of consumer satisfaction are:

(1) The waiting time is relatively long, the queue time is more than two hours;

(2) Some of the spare parts are not available, so it is time for order to the Yamaha;

Corresponding author: Genoveva, Ph.D. candidate in Management Science, Faculty of Economics, YAI Persada University, Jakarta, Indonesia; lecturer, Management Study Program, Faculty of Business, President University, Indonesia; research fields: marketing, entrepreneurship, and general management. E-mail: genoveva.claudia@gmail.com. 
(3) The price of original spare parts in Yamaha workshop considered as more expensive, because consumers do not know the differences with counterfeit parts that are sold cheaper at another workshop.

Based on Zeithaml and Bitner (2012), customer satisfaction is influenced by various factors, they are consist of: product quality, price, and personal circumstances of the customer. The theory of Zeithaml and Bitner (2012) said: Long waiting times and the unavailability of spare part are quality of service, while an understanding of the originality of spare parts is a factor of the customer's situation and personal.

The researcher also found that, in the last three years (2012-2014), 39.09\% of customers do not re-purchase after the free services program. According to Tjiptono (2011), indicator of customer loyalty is that they make re-purchase and recommend to others.

\section{Review of Literature}

\section{Brand Image}

According to Tjiptono (2005), brand image is a description of the association and the confidence of consumers toward a particular brand. According to Kotler (2012), brand image is a number of beliefs about the brand. According to Aaker (2014), the image of the brand is regarded as "How the brand is perceived by consumers". With regard to the perception, according to Davis, like humans, the brand can also be described by adjectives, adverbs, or phrase. Aaker also said that brand image has two components, namely, brand association and personnal brand.

The dimensions of brand image in this research are proposed by Schiffman and Kanuk (2006), who stated that the factors forming the image of the brand are:

(1) The quality is relating to the quality of the goods offered by the manufacturer with a certain brand;

(2) Can be trusted is opinions or agreements relating to that formed by the public on a product that is consumed;

(3) Usability or benefit is associated with the function of a goods that can be used by consumers;

(4) Service deals with the task of manufacturers in serving customers;

(5) Risk is related to the size of a result or profit and loss that may be experienced by consumers;

(6) The price in this case relates to the level or the extent of the amount of money spent to influence a consumer product, it can also affect the image of the long-term;

(7) The image is owned by the brand itself, in the form of a view, the agreement and information related to a particular brand of product.

\section{Perceived Service Quality}

According to Kotler (2012), "A service is an activity or benefit that one party can offer to another party. Intangible and does not result in the ownership of anything". Kotler and Keller (2009) said, "The service is any act or performance offered by one party for the benefit of another party that has an intangible nature and does not lead to transfer of ownership". Lovelock and Wright (2007) described the service as an economic activity that is offered by one party to another party, in a performance at a certain time to obtain the results desired by the recipient or the owner who is responsible for a particular object or asset.

The dimensions of quality service perceptions in this study were as follows (Zeithaml \& Bitner, 2012):

(1) Reliability is ability to serve intangible accordance with trustworthy and promised with accuracy, consistency, and appropriateness of services; 
(2) Responsiveness is the alertness of employees in helping customers and providing fast service and responsiveness, include: alertness of employees in serving customers, employees' speed in handling the transaction, and the handling of complaints;

(3) Assurance includes the ability of employees on proper knowledge of the product, the quality of the hospitality, attention, and courtesy in providing services, skills in providing information, the ability to provide security in the use of services offered, and the ability to instill customer confidence in the company;

(4) Empathy is the individual attention given by the company to customers, like the ease of contacting the company, the employee's ability to communicate with customers, and business enterprises to understand the wants and needs of its customers;

(5) Tangible is namely the appearance of physical facilities such as buildings and front office, availability of parking, cleanliness, tidiness, and comfort of the room, completeness communications equipment, and employee appearance.

\section{Customer Satisfaction}

Consumer satisfaction is the feeling of someone who is satisfied or otherwise after comparing between reality and expectations received from a product or service (Kotler, 2012). Zeithaml and Bitner (2012) suggested that satisfaction is not only a much broader concept than just assessment of service quality, but also influenced by other factors. As shown in Figure 1, customer satisfaction is influenced by customer perception of service quality, product quality, price, and by situational factors and personal factors of the customer.

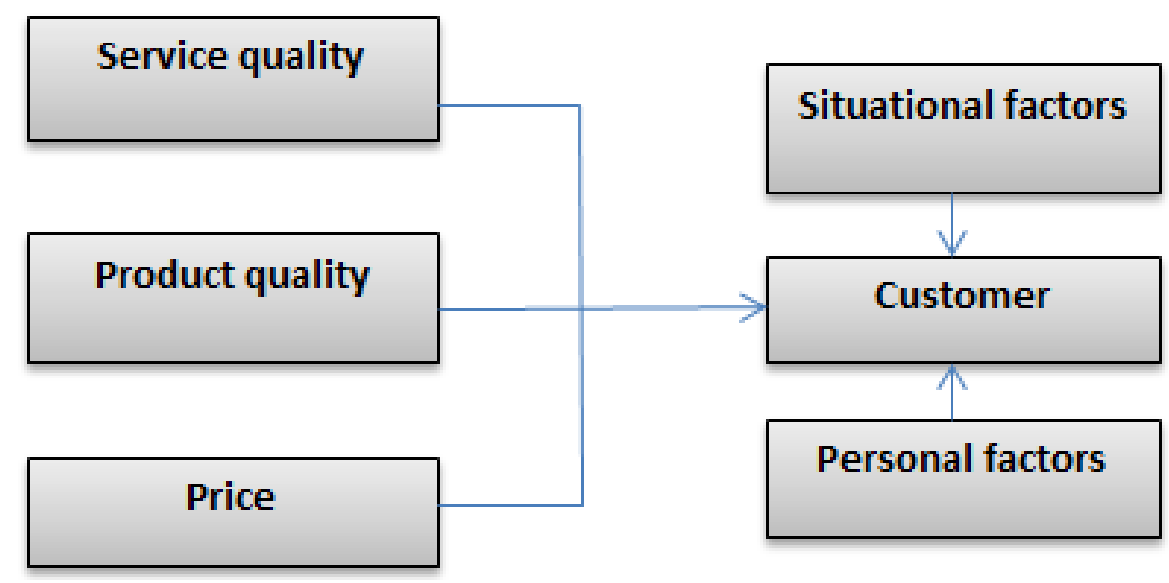

Figure 1. Model of customer satisfaction. Source: Zeithaml and Bitner (2012).

According to Wilkie (2004), it states that there are five elements in customer satisfaction, such as:

(1) Expectation is consumer expectation for a good or service that has been set up before consumers purchase goods or services;

(2) Performance is consumer experience on the performance of the actual goods or services when they used without impact by their expectations;

(3) Comparison is done by comparing the expectations of the performance of the goods or services before buying and the perception of the actual performance of the goods or services;

(4) Confirmation/Disconfirmation is consumer expectations are influenced by their experiences to use of the mark from the goods or services different from others. Confirmation occurs when expectations correspond to 
actual performance products. Otherwise, disconfirmation occurs when expectations are higher or lower than the actual performance of the product.

\section{Customer Loyalty}

Consumer loyalty according to Kotler and Armstong (2012) is derived from the fulfillment of customer expectation, while the expectation comes from the experience of previous purchases by consumers, the opinions of friends and relatives, an information from the marketer or a competitor. There are some reasons for developing long-term relationships with consumers:

(1) The high cost of new customer acquisition;

(2) The loyal customers tend to spend more;

(3) The satisfied customers will recommend company services or product;

(4) The loyal customers will emphasize a competitor from the market.

So if the customers are satisfying, they will have loyal and repeat purchase, also have the positive word of mouth. Finally, the company will get more new customers (Zeithaml \& Bitner, 2012) (see Figure 2).

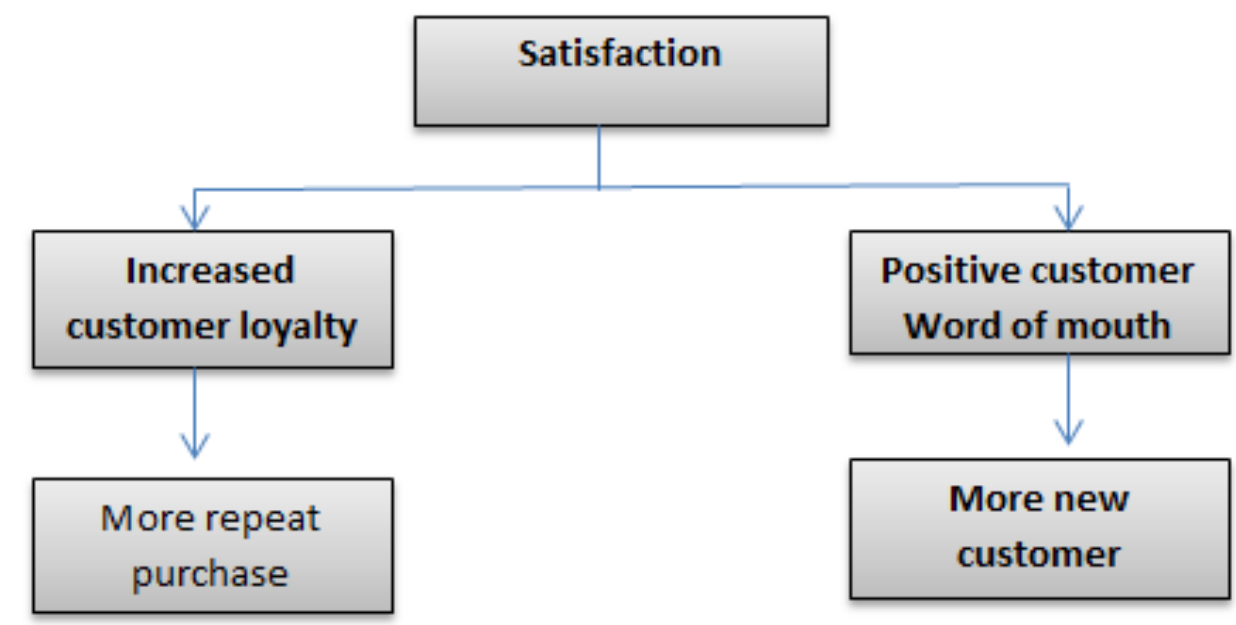

Figure 2. Customer satisfaction and loyalty. Source: Zeithaml and Bitner (2012).

\section{The Previous Research}

Upamannyu and Bhakar (2014) in "Effect of Customer Satisfaction on Brand Image \& Loyalty Intention" result that they are influences of customer satisfaction, customer loyalty, and brand image. Jeon (2009) also found that the loyalty of online customer has related with the quality of the web services. The result has also shown that the quality of website services has direct influences on customer satisfaction and customer loyalty. The customers will re-purchase if they are satisfied.

In Journal of Social and Development Sciences, Tu, Wang, and Chang (2012) in research about "Corporate Brand Image and Customer Satisfaction on Loyalty: An Empirical Study of Starbucks Coffee in Taiwan" result that the brand image of company significance influence on customer satisfaction and customer loyalty, the strength of customer satisfaction also impact on customer loyalty. The Pakistan authors Ahmed, Majid, Nadeem, and Jalbani (2013) found that the quality services have positive and strength correlation on brand loyalty, with customer satisfaction as mediating variable. The service quality that serves by Pakistan mobile communication is important to make the customer loyal. Andreassen and Lindestad (1998) found that 
the company image and customer satisfaction influence on customer loyalty. The company image has direct impact on customer, otherwise the customer satisfaction has indirect impact to customer.

\section{Data Analysis and Interpretation of Research}

\section{Data of Respondents}

The total number of respondents is 355 with the composition of the male as much as $73 \%$ and females are $27 \%$. The majority of respondents are age categories which range from 27 to 37 years old with total $41 \%$ (see Figure 3).

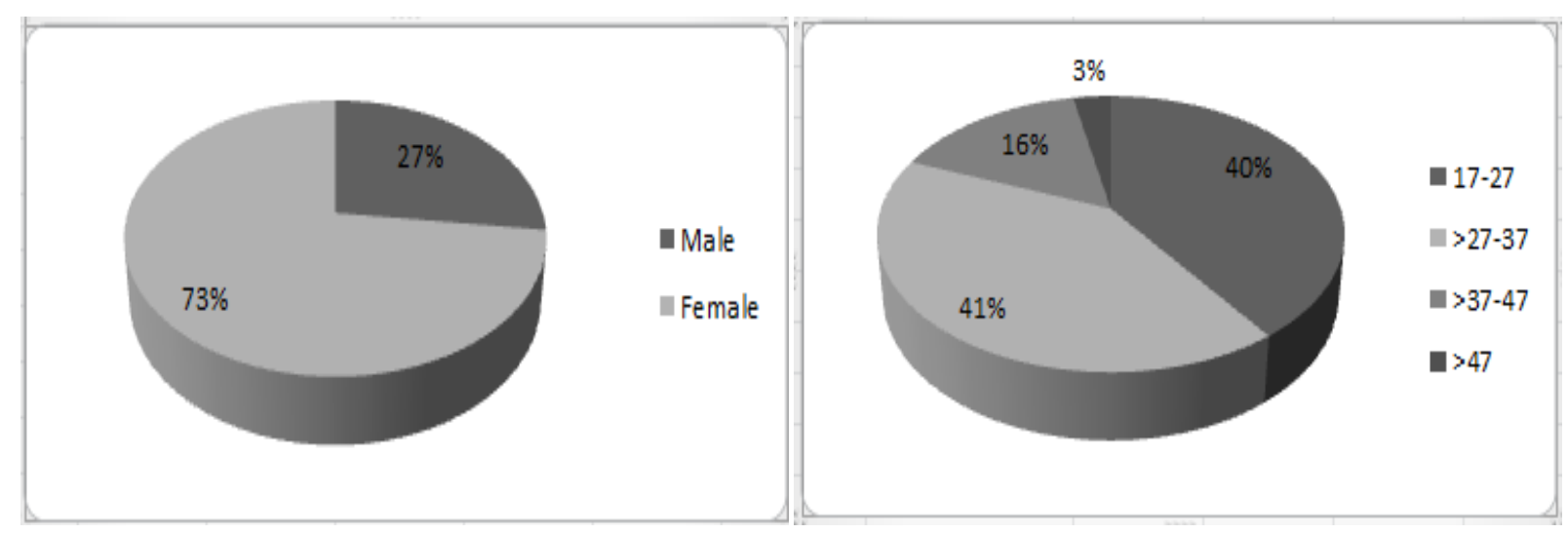

Figure 3. Gender and age of respondents. Source: Questionnaire, processed by SPSS 2.0.

Figure 4 describes the frequency of occupation of respondents, majority of them are private employees with total $59 \%$, the figure also describes the frequency of educational background, and majority of them are senior high school with total $65 \%$.

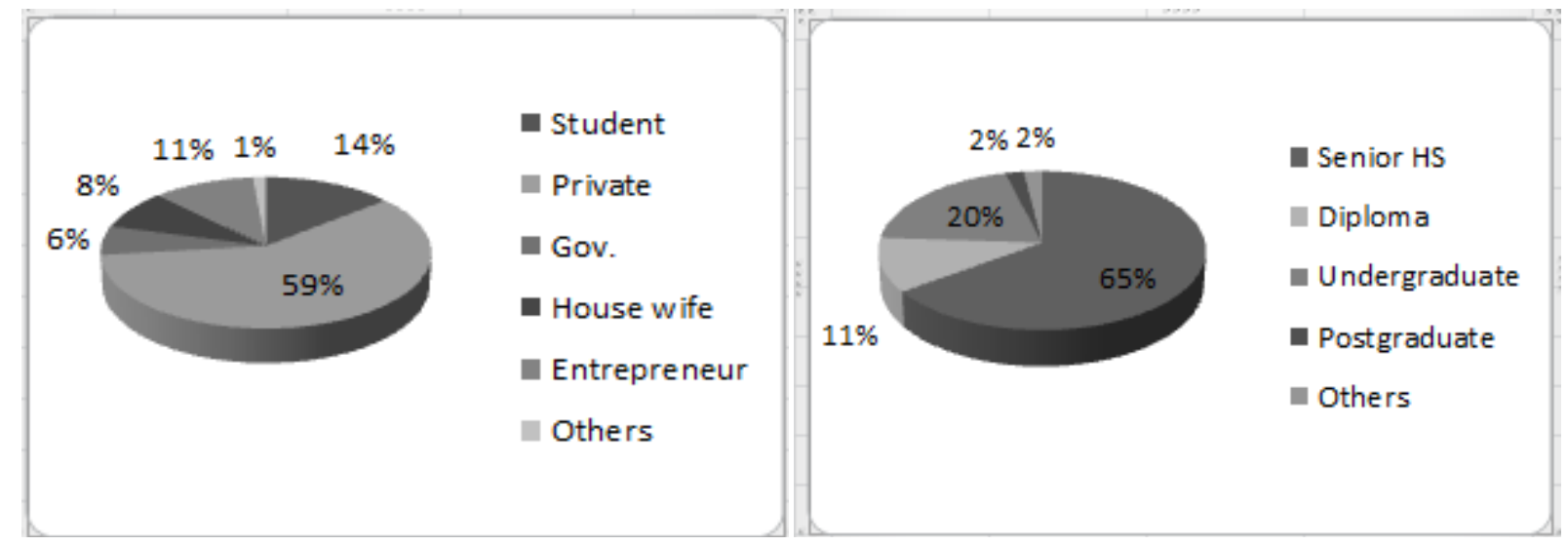

Figure 4. Occupation and education of respondents. Source: Questionnaire, processed by SPSS 2.0.

Figure 5 describes the frequency of monthly expenses, majority of them are ranging from one to two million IDR with total $37 \%$, it also shows the number of motorcycle owned. The majority of customers have one unit motorcycle $(63 \%)$.

Figure 6 describes the frequency of owned of other motorcycle brands, the majority of respondents do not have other brands, the total are $72 \%$ and a small number respondents have the other brands, they are $28 \%$. The majority respondents who have the other brand show that 79 of the respondents choose Honda Motorcycle. 


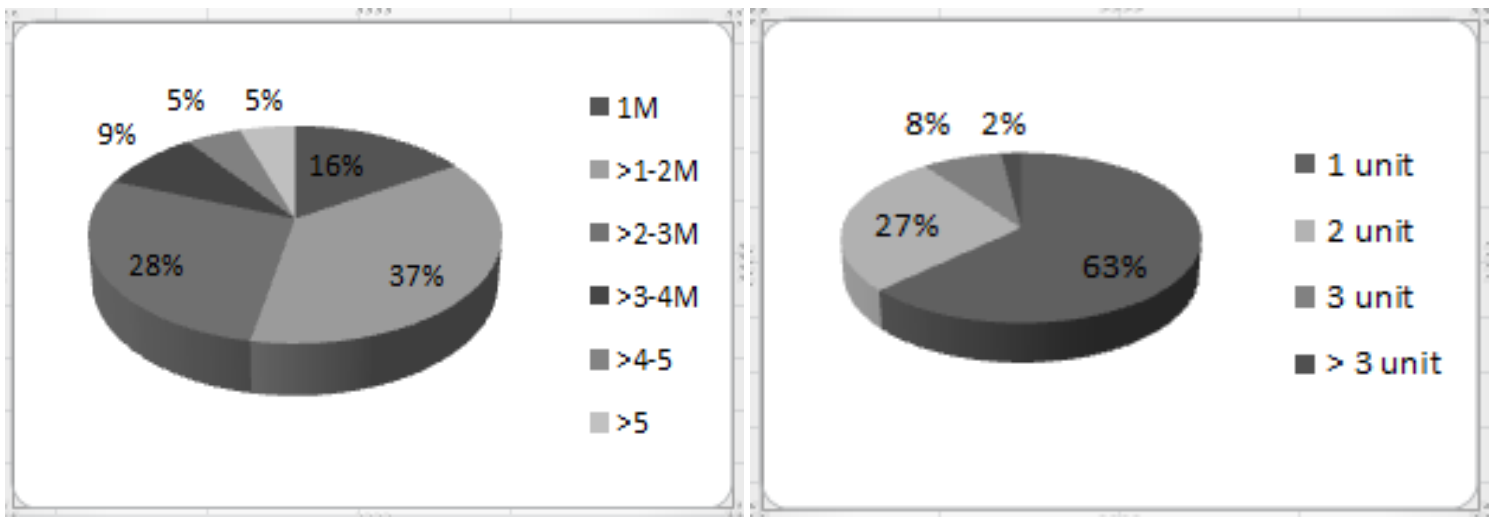

Figure 5. Monthly expenses and number of motorcycle owned. Source: Questionnaire, processed by SPSS 2.0.

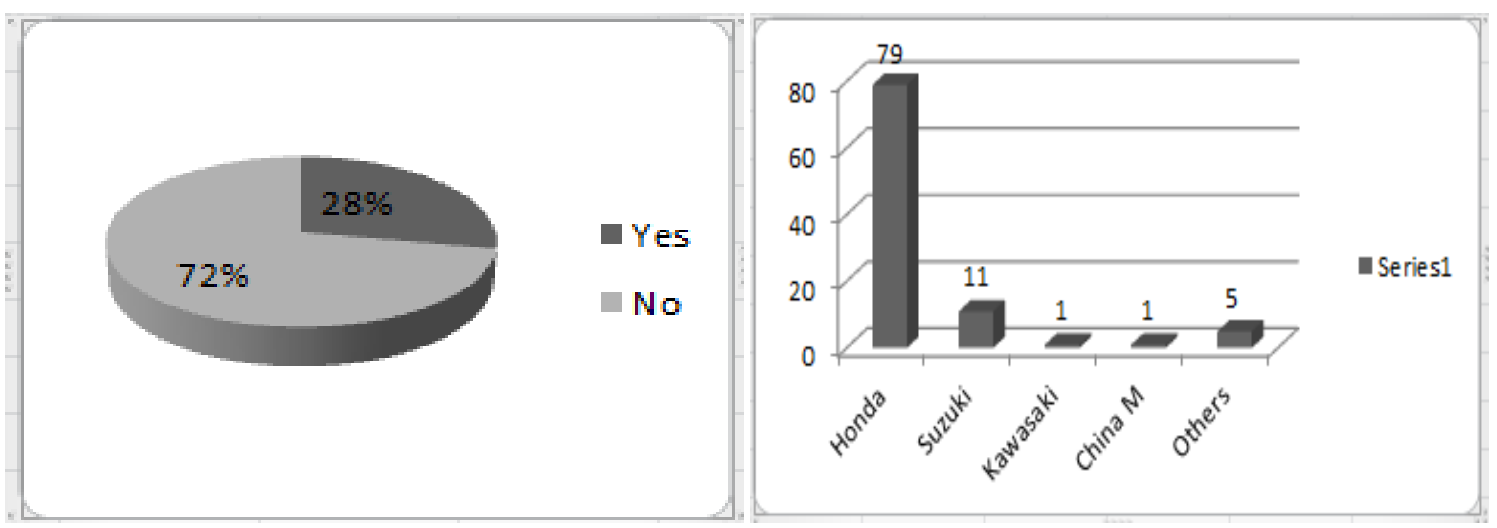

Figure 6. The number of owned of other motorcycle brand. Source: Questionnaire, processed by SPSS 2.0.

\section{Confirmatory Factor Analysis (CFA)}

Brand image. Based on LISREL output in Table 1, it can be seen that standardized loading factors value from each observed variables are $\geq 0.50$, which means these all of observed variables are valid and significant statistically. Based on Hair, Joseph, Black, Babin, and Andersen (2010), the good reliability is if the Construct Reliability (CR) $0.97 \geq 0.70$ and Variance Extracted (VE) is $0.83 \geq 0.50$. From the output calculation in Table 1 below, all of the dimensions have good reliability $\left(\mathrm{X}_{1}, \mathrm{X}_{2}, \mathrm{X}_{3}, \mathrm{X}_{4}, \mathrm{X}_{5}, \mathrm{X}_{6}, \mathrm{X}_{7}\right)$. The measurement equations for observed overall $\mathrm{t}$-value produced for each observed variables are $\geq 1.96$ which means that all of items are significant statistically with $5 \%$ level of significance.

Table 1

Validity and Reliability of Brand Image

\begin{tabular}{|c|c|c|c|c|c|c|}
\hline Indicator & Standard loading factor (SLF) $\geq 0.5$ & t-value & Standard error & $\mathrm{CR} \geq 0.70$ & $\mathrm{VE} \geq 0.50$ & Remark \\
\hline Brand image & & & & 0.97 & 0.83 & Reliable \\
\hline $\mathrm{X}_{1}$ & 0.87 & 12.08 & 0.41 & & & Valid \\
\hline $\mathrm{X}_{2}$ & 0.86 & 12.44 & 0.47 & & & Valid \\
\hline $\mathrm{X}_{3}$ & 0.85 & 14.94 & 0.31 & & & Valid \\
\hline $\mathrm{X}_{4}$ & 0.84 & 15.46 & 0.35 & & & Valid \\
\hline $\mathrm{X}_{5}$ & 0.88 & 14.76 & 0.38 & & & Valid \\
\hline $\mathrm{X}_{6}$ & 0.82 & 13.60 & 0.38 & & & Valid \\
\hline $\mathrm{X}_{7}$ & 0.83 & 13.13 & 0.38 & & & Valid \\
\hline
\end{tabular}

Note. Source: Questionnaire, processed by LISREL 8.7. 
Perceived service quality. The output calculation on Table 2 below shows that all of the dimensions have good reliability $\left(\mathrm{X}_{8}, \mathrm{X}_{9}, \mathrm{X}_{10}, \mathrm{X}_{11}, \mathrm{X}_{12}\right)$. The measurement equations for observed overall $\mathrm{t}$-value produced for each observed variables are $\geq 1.96$ which means that all of items are significant statistically with $5 \%$ level of significance.

Table 2

Validity and Reliability of Perceived Service Quality

\begin{tabular}{|c|c|c|c|c|c|c|}
\hline Indicator & $\mathrm{SLF} \geq 0.5$ & t-value & Standard error & $\mathrm{CR} \geq 0.70$ & $\mathrm{VE} \geq 0.50$ & Remark \\
\hline Perceived service quality & & & & 0.98 & 0.91 & Reliable \\
\hline $\mathrm{X}_{8}$ & 0.84 & 12.50 & 0.47 & & & Valid \\
\hline $\mathrm{X}_{9}$ & 0.85 & 15.82 & 0.44 & & & Valid \\
\hline $\mathrm{X}_{10}$ & 0.96 & 16.42 & 0.40 & & & Valid \\
\hline $\mathrm{X}_{11}$ & 0.94 & 15.91 & 0.45 & & & Valid \\
\hline $\mathrm{X}_{12}$ & 0.89 & 16.42 & 0.33 & & & Valid \\
\hline
\end{tabular}

Note. Source: Questionnaire, processed by LISREL 8.7.

The output calculation on Table 3 below shows that all of the dimensions have good reliability $\left(\mathrm{Y}_{1}, \mathrm{Y}_{2}, \mathrm{Y}_{3}\right.$, $\mathrm{Y}_{4}$ ). The measurement equations for observed overall $\mathrm{t}$-value produced for each observed variables are $\geq 1.96$ which means that all of items are significant statistically with $5 \%$ level of significance.

Table 3

Validity and Reliability of Customer Satisfaction

\begin{tabular}{|c|c|c|c|c|c|c|}
\hline Indicator & $\mathrm{SLF} \geq 0.5$ & t-value & Standard error & $\mathrm{CR} \geq 0.70$ & $\mathrm{VE} \geq 0.50$ & Remark \\
\hline Customer satisfaction & & & & 0.98 & 0.91 & Reliable \\
\hline $\mathrm{Y}_{1}$ & 0.89 & 14.82 & 0.33 & & & Valid \\
\hline $\mathrm{Y}_{2}$ & 0.96 & 19.18 & 0.26 & & & Valid \\
\hline $\mathrm{Y}_{3}$ & 0.90 & 15.28 & 0.30 & & & Valid \\
\hline $\mathrm{Y}_{4}$ & 0.92 & 17.11 & 0.29 & & & Valid \\
\hline
\end{tabular}

Note. Source: Questionnaire, processed by LISREL 8.7.

Customer loyalty. The output calculation on Table 4 below shows that all of the dimensions have good reliability $\left(\mathrm{Y}_{5}, \mathrm{Y}_{6}, \mathrm{Y}_{7}, \mathrm{Y}_{8}, \mathrm{Y}_{9}, \mathrm{Y}_{10}\right)$. The measurement equations for observed overall t-value produced for each observed variables are $\geq 1.96$ which means that all of items are significant statistically with $5 \%$ level of significance.

Table 4

Validity and Reliability of Customer Loyalty

\begin{tabular}{|c|c|c|c|c|c|c|}
\hline Indicator & $\mathrm{SLF} \geq 0.5$ & t-value & Standard error & $\mathrm{CR} \geq 0.70$ & $\mathrm{VE} \geq 0.50$ & Remark \\
\hline Customer loyalty & & & & 0.97 & 0.86 & Reliable \\
\hline $\mathrm{Y}_{5}$ & 0.85 & 15.84 & 0.29 & & & Valid \\
\hline $\mathrm{Y}_{6}$ & 0.88 & 16.06 & 0.35 & & & Valid \\
\hline $\mathrm{Y}_{7}$ & 0.97 & 18.11 & 0.32 & & & Valid \\
\hline $\mathrm{Y}_{8}$ & 0.95 & 17.54 & 0.34 & & & Valid \\
\hline $\mathrm{Y}_{9}$ & 0.82 & 18.10 & 0.30 & & & Valid \\
\hline $\mathrm{Y}_{10}$ & 0.79 & 13.38 & 3.32 & & & Valid \\
\hline
\end{tabular}

Note. Source: Questionnaire, processed by LISREL 8.7. 


\section{Structural Model Analysis}

After doing the calculation and analysis of CFA, then, the next step researcher does is an analysis of the structural model, consists of: (1) model fit test; and (2) the analysis of causal relationships.

Structural model fit test. From analysis below (see Table 5) can be seen that not all measurements of goodness of fit show good fit value and marginal fit. However, this model qualified as good model, because the main measurements used is RMSEA (Root Mean Square Error of Approximation) value (Hair et al., 2010). In this model, RMSEA is exactly $<0.10$ which is 0.076 , shows that overall model is good fit or marginal fit and has good degree of precision.

Table 5

Fit Test (Goodness of Fit Structural Model)

\begin{tabular}{|c|c|c|c|}
\hline Measurements GOF (goodness of fit) & Standard of measurement & Estimation result & Description \\
\hline \multicolumn{4}{|c|}{ Measurement of absolute fit } \\
\hline GFI (goodness of fit index) & GFI $>0.90$ & 0.85 & Marginal fit \\
\hline RMSEA & $<0.074$ RMSEA 0.088 & 0.081 & Good fit \\
\hline \multicolumn{4}{|c|}{ Measurement of incremental fit } \\
\hline NNFI (non-normed fit index) & NNFI $\geq 0.90$ & 0.98 & Good fit \\
\hline NFI (normed fit index) & $\mathrm{NFI} \geq 0.90$ & 0.98 & Good fit \\
\hline AGFI (adjusted goodness of fit index) & $\mathrm{AGFI} \geq 0.90$ & 0.82 & Marginal fit \\
\hline RFI (relative fit index) & RFI $>0.90$ & 0.98 & Good fit \\
\hline IFI (incremental fit index) & IFI $>0.90$ & 0.99 & Good fit \\
\hline CFI (comparative fit index) & $\mathrm{CFI} \geq 0.90$ & 0.99 & Good fit \\
\hline
\end{tabular}

Note. Source: Questionnaire, processed by LISREL 8.7.

Path analysis. After analyzing the results of the structural model fit, the following analysis is done by performing an analysis of path. Statistical testing for path analysis of structural model is made with a level of significance of $5 \%$, so the critical value from t-value is \pm 1.96 . Table 6 and Figure 7 show that hypotesis is not significant, there are BI (brand image)-CS (customer satisfaction) with $1.86<1.96$ and PSQ (perceived service quality)-CL (customer loyalty) with $-0.43<1.96$.

Table 6

Path Analysis

\begin{tabular}{llll}
\hline Path & Standardized koefisien & t-value/F & Conclusion \\
\hline $\mathrm{BI} \rightarrow \mathrm{CS}$ & 0.25 & 1.86 & Not significant \\
$\mathrm{PSQ} \rightarrow \mathrm{CS}$ & 0.69 & 4.95 & Significant \\
$\mathrm{BI}$ and PSQ $\rightarrow$ CS & 0.13 & 783 & Significant \\
$\mathrm{BI} \rightarrow \mathrm{CL}$ & 0.95 & 84.47 & Significant \\
$\mathrm{PSQ} \rightarrow \mathrm{CL}$ & -0.08 & -0.43 & Not significant \\
$\mathrm{CS} \rightarrow \mathrm{CL}$ & 0.30 & 2.24 & Significant \\
$\mathrm{BI}, \mathrm{PSQ}$, and CS $\rightarrow \mathrm{CL}$ & 0.24 & 370 & Significant \\
\hline
\end{tabular}

Note. Source: Questionnaire, processed by LISREL 8.7. 


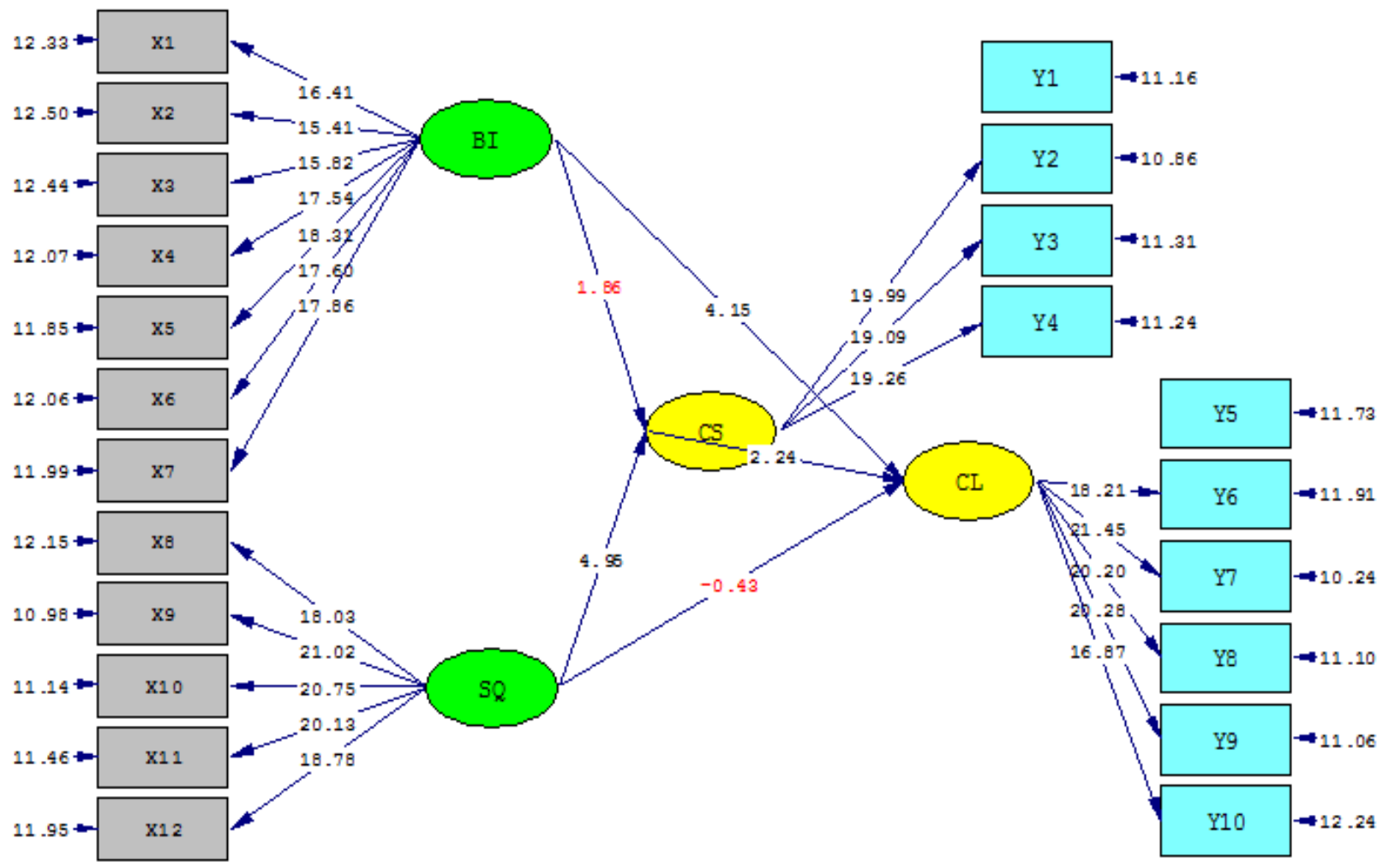

Chi-Square $=671.89, \mathrm{df}=203, \mathrm{p}-\mathrm{value}=0.00000, \mathrm{RMSEA}=0.081$

Figure 7. t-value model. Source: Questionnaire, processed by LISREL 8.7. Notes. $\mathrm{X}_{1}=\mathrm{BI} ; \mathrm{X}_{2}=\mathrm{SQ}$ (Service Quality); $\mathrm{Y}_{1}=\mathrm{CS} ; \mathrm{Y}_{2}=\mathrm{CL}$.

\section{Hypothesis Testing}

Analysis of hypothesis testing is performed with a 5\% significance level resulting in a t-value \pm 1.96 . The hypothesis was accepted when the t-value obtained $\geq 1.96$, on the other side of the hypothesis will be rejected when the $\mathrm{t}$-value obtained $\leq 1.96$. Based on this $\mathrm{t}$-value, we can see that this model can support the data. The conclusion of hypothesis testing shows (see Table 7) that two hypotheses declined, they are:

(1) Brand image negatively influences on customer satisfaction with t-value 1.86;

(2) Perceived service quality negatively influences on customer loyalty with t-value -0.43 .

Table 7

Hypothesis Test

\begin{tabular}{lll}
\hline Hypothesis & Description & Conclusion \\
\hline $\mathrm{H}_{1}$ & Brand image influences on customer satisfaction & Hypothesis declined \\
$\mathrm{H}_{2}$ & Perceived service quality influences on customer satisfaction & Hypothesis accepted \\
$\mathrm{H}_{3}$ & $\begin{array}{l}\text { Brand image and perceived service quality simultaneously } \\
\text { influence on customer satisfaction }\end{array}$ & Hypothesis accepted \\
$\mathrm{H}_{4}$ & Brand image influences on customer loyalty & Hypothesis accepted \\
$\mathrm{H}_{5}$ & Perceived service quality influences on customer loyalty & Hypothesis declined \\
$\mathrm{H}_{6}$ & Customer satisfaction influences on customer loyalty & Hypothesis accepted \\
$\mathrm{H}_{7}$ & Brand image, perceived service quality, and customer satisfaction & Hypothesis accepted \\
\hline
\end{tabular}

Note. Source: Questionnaire, processed by LISREL 8.7. 


\section{Conclusion and Managerial Implications}

\section{Conclusion}

This research conclusion is that two hypotheses are not significant, they are: brand image influences on customer satisfaction, but not significance, also perceived service quality influences on customer loyalty, but not significance. This result in line with Malik, Ghafoor, and Iqbal (2012), they found that as partially brand image not significance on customer satisfaction. The questionnaire confirmed that some of questions show that consumers give the lowest score for the handling of complaints. This is in line with the opinion of Kotler (2012), which states that the brand is a statement of the seller to consistently provide the best features, benefits, and certain services to the buyer, is not only a symbol that distinguishes a particular company's products by competitors. This means that when consumers visit any Yamaha workshop, all workshops consistently deliver service included in the handling of complaints.

Perceived service quality influences on customer satisfaction, also significance with $46.61 \%$. This is in accordance with Tjiptono (2005), "Another way to differentiate is to consistently provide quality services better than the competitors". The quality of service itself is influenced by two variables, they are such as perceived services and services expected. When services are perceived smaller than expected, then the customer will be no longer interested in the service provider concerned. If the opposite is true (perceived $>$ expected), it is possible that customers would use the service provider again.

Brand image, perceived service quality, and customer satisfaction simultaneously influence on customer loyalty, also significance with 76\%. The result of Andreassen and Lindestad (1998) concludes that the corporate image, quality of service, and customer satisfaction relate to customer loyalty. The company image has a direct impact on the customer, the customer will re-purchase when they are satisfying.

\section{Managerial Implications}

Based on the conclusions, because brand image and perceived service quality influence customer satisfaction is $87 \%$, so improving the strong brand image and also the service quality can be as a company concern. In this research, the waiting time in services is not currently satisfying. Yamaha workshop can be an evaluation of the waiting time for solving the problem, for the example, with the booking service, so the workshop can set the time arrival accordingly.

Brand image, perceived service quality, and customer satisfaction influence customer loyalty is $76 \%$, so improving customer loyalty is very important, the workshop does not handle complaints properly. Yamaha workshop needs to pay attention to customer complaints with evaluated all of customer complaint and solve the complaints as soon as possible.

\section{References}

Aaker, D. (2014). Aaker on branding: 20 principles that drive success. New York: Morgan James Publishing.

Abd-El-Salam, E. M., Shawky, A. Y., \& El-Nahas, T. (2013). The impact of corporate image and reputation on service quality, customer satisfaction and customer loyalty: Testing the mediating role (case analysis in an international service company). The Business \& Management Review, 3(2), 177-196.

Abdullah, N. (2013). The number of workshops are not in accordance with the number of vehicles. Retrieved from http://www.bisnis.com

Ahmed, N., Majid, M., Nadeem, M., \& Jalbani, S. M. (2013). The impact of service quality on brand loyalty: Mediating role of customer satisfaction. European Journal of Management Sciences, 1(1), 30-41. 
Andreassen, T. W., \& Lindestad, B. (1998). Customer loyalty and complex services: The impact of corporate image on quality, customer satisfaction and loyalty for customers with varying degrees of service expertise. International Journal of Service Industry Management, 9(1), 7-23.

Asmai, I., \& Luthfi, Z. (2011). The influence customer satisfaction and customer trust on customer loyalty: A case study of switching cost as intermediate variable. Journal of Siasat Bisnis, 15(1), 55-66.

Bae, Y. H. (2010). Three essays on customer satisfaction-Customer loyalty association. Retrieved from http://ir.uiowa. edu/etd/3255

Beneke, J., Hayworth, C., Hobson, R., \& Mia, Z. (2012). Examining the effect of retail service quality dimensions on customer satisfaction and loyalty: The case of the supermarket shopper. Acta Commercii, 12(1), 27-43.

Boone, L., \& Kurtz, D. (2014). Marketing contemporary. Mason: South-Western Cengage Learning.

Chang, P. K., \& Chong, H. L. (2011). Customer satisfaction and loyalty on service provided by Malaysian telecommunication companies. Proceedings from International Conference on Electrical Engineering and Informatics. July 17-19, Bandung, Indonesia.

Cooper, D. R., \& Schindler, P. S. (2014). Business research method (12th ed.). New York: McGraw-Hill Irwin.

Diposumarto, N. S., \& Susilo, W. H. (2013). Marketing research: Application of SPSS, Lisrel and Amos on services marketing research. Jakarta: In Media.

Durianto, D., Sugiarto, \& Sitinjak, T. (2004). The strategy to conquer the market by brand equity and brand behavior research. Jakarta: Gramedia Pustaka Utama.

Ferrell, O. C., \& Hartline, M. D. (2011). Marketing strategy (5th ed.). Boston: South-Western Cengage Learning.

Grewal, D., \& Levy, M. (2014). Marketing (4th ed.). New York: McGraw-Hill Irwin.

Hair Jr, Joseph, F., Black, W. J., Babin, B. J., \& Andersen, R. (2010). Multivariate data analysis (6th ed.). New Jersey: Prentice Hall.

Haq, A. U. (2012). Satisfaction towards customer loyalty in auto-mobile industry of Pakistan. International Journal of Management, 2(4), 363-371.

Hawkins, D. I., \& Mothersbaugh, D. L. (2010). Consumer behavior (11th ed.). New York: McGraw-Hill Irwin.

Industry Assosiation of Motorcycle Indoensia. (2015). The motorcycle sales of 2010-2014. Retrieved from http://www.aisi.co.id

Ishaqa, M. I. (2012). Perceived value, service quality, corporate image and customer loyalty: Empirical assessment from Pakistan. Serbian Journal of Management, 7, 25-36.

Jeon, M. (2009). Impact of perceived website service quality on customer e-loyalty on a logging website. Ph.D. dissertation, Iowa State University.

Kotler, P. (2012). Marketing management (millenium ed.). New Jersey: Prentice Hall Inc.

Kotler, P., \& Amstrong, G. (2012). Principles of marketing. New Jersey: Pearson Prentice Hall.

Kotler, P., \& Keller, K. (2009). Marketing management (14th ed.). New Jersey: Prentise Hall.

Kumar, V., Batista, L., \& Maull, R. (2011). The impact of operations performance on customer loyalty. Service Science, 3, 158-171.

Lovelock, C. H., \& Wright, L. K. (2007). Services marketing. Jakarta: Indeks.

Maholtra, N. K. (2010). Marketing research: An applied orientation (5th ed.). New Jersey: Pearson Education.

Malik, F., Yaqoob, S., \& Aslam, A. S. (2012). The impact of price perception, service quality, and brand image on customer loyalty (study of hospitality industry in Pakistan). Interdisciplinary Journal of Contemporary Research in Business, 4(5), 487.

Malik, M. E., Ghafoor, M. M., \& Iqbal, H. K. (2012). Impact of brand image, service quality and price on customer satisfaction in Pakistan telecommunication sector. International Journal of Business and Social Science, 3(23), 123-129.

Martisiute, S., Vilutyte, G., \& Grundey, D. (2010). Product or brand? How interrelationship between customer satisfaction and customer loyalty work. European Journal of Interdisciplinary Studies, 2(1), 5-11.

Qing, Z. (2012). Perceived service quality, customer satisfaction, and customer loyalty: The moderating effect of switching costs in China mobile telecommunication industry. Grenoble: Ecole De Management, Management Technology and Innovation.

Rahman, M. S. (2012). Service quality, corporate image and customer's satisfaction towards customer's perception: An exploratory study on telecom customers in Bangladesh. Business Intelligence Journal, 5(1), 56-63.

Ramaswany. (2013). Marketing management. New Delhi: McGraw-Hill Education (India), Private limited.

Rekarti, E. (2012). The knowledge and relation of brand on customer purchase. Journal of Economics, 11, 40-57.

Saleem, H., \& Raja, N. S. (2014). The impact of service quality on customer satisfaction, customer loyalty and brand image: Evidence from hotel industry of Pakistan. IOSR Journal of Business and Management, 16(1), 117-122. 
Schiffman, L. G., \& Kanuk, L. L. (2006). Consumer behavior (8th ed.). New Jersey: Pearson Prentice Hall.

Sondoh Jr, Stephen, L., Omar, M. W., \& Wahid, N. A. (2007). The effect of brand image on overall satisfaction and loyalty intention in the context of color cosmetic. Asian Academy of Management Journal, 12(1), 83-107.

Tjiptono, F. (2005). Prinsip-prinsip total quality service. Yogyakarta: Penerbit Andy.

Tu, Y.-T., Li, M.-L., \& Chih, H.-C. (2013). An empirical study of corporate brand image, customer perceived value and satisfaction on loyalty in shoe industry. Journal of Economics and Behavioral Studies, 5(7), 469-483.

Tu, Y.-T., Wang, C.-M., \& Chang, H.-C. (2012). Corporate brand image and customer satisfaction on loyalty: An empirical study of Starbucks Coffee in Taiwan. Journal of Social and Development Sciences, 3(1), 24-32.

Upamannyu, N. K., \& Bhakar, S. S. (2014). Effect of customer satisfaction on brand image \& loyalty intention: A study of cosmetic product. International Journal of Research in Business and Technology, 4(1), 296-307.

Wilkie, W. L. (2004). Customer behavior. New York: John Wiley \& Sons, Inc.

Zeithaml, V. A., \& Bitner, M. J. (2012). Service marketing (international ed.). New York: McGraw Hill Inc. 